\title{
SYSTEMIC INFLAMMATION, SYSTEMIC EFFECTS AND COMORBIDITIES IN CHRONIC OBSTRUCTIVE PULMONARY DISEASE
}

\author{
Romana Susa1,2, Zorica Lazic 1,2, Ivan Cekerevac1,2 \\ ${ }^{1}$ Clinical Centre Kragujevac, Clinic for Pulmonology, Kragujevac, Serbia \\ ${ }^{2}$ Faculty of Medical Sciences, University of Kragujevac, Kragujevac, Serbia
}

\section{SISTEMSKA INFLAMACIJA, SISTEMSKI EFEKTI I KOMORBIDITETI KOD HRONIČNE OPSTRUKTIVNE BOLESTI PLUĆA}

\author{
Romana Sušal,2, Zorica Lazićl,2, Ivan Čekerevac1,2 \\ ${ }^{1}$ Klinički centar Kragujevac, Klinika za pulmologiju, Kragujevac \\ ${ }^{2}$ Fakultet medicinskih nauka, Univerzitet u Kragujevcu, Kragujevac
}

\section{ABSTRACT}

Chronic obstructive pulmonary disease (COPD) is known to be characterized by inflammation both in the stable phase of the disease and during exacerbation. It has been shown that certain inflammatory mediators have a high level in systemic circulation, indicating systemic inflammation in COPD. The first recognized systemic effect of COPD is a disorder of the state of nourishment. Certain diseases, including COPD, can lead to cachexia where patients lose muscle mass despite adequate caloric intake. Inflammation in COPD also has an effect on increased protein catabolism, which leads to a decrease in body weight. Increased activity of enzymes matrix metalloproteinases family (MMP) in patients with COPD can lead to lung tissue destruction and the development of osteoporosis. It is considered that the most important role in the association between COPD and CVD disease is systemic inflammation. Low level of inflammation in small airways in COPD and Atherosclerotic plaques, may be a potential factor in the development of both pathological processes. Systemic manifestations of COPD include numerous endocrine disorders of the pituitary gland, thyroid gland, gonads, adrenal glands and pancreas. The mechanisms by which HOBP affects the endocrine function are not entirely clear, but are likely to include hypoxemia, hypercapnia, systemic inflammation, and the use of systemic glucocorticoids. Explanation for significant depressive disorder in more advanced stages in COPD can be expressive dyspnoea, decreased physical activity, worse exercise tolerance, frequent exacerbations and systemic inflammation which can lead to further physical activity decrease, social isolation, fear, and depression.

Key words: COPD, systemic inflammation, systemic effect, comorbidity.

\section{INTRODUCTION}

Chronic obstructive pulmonary disease (COPD) is known to be characterized by inflammation both in the stable phase of the disease and during exacerbation. In addition to local inflammation in the respiratory tract, pulmonary parenchyma, and blood vessels of the lung, it has been shown that certain inflammatory mediators have

\section{SAŽETAK}

Hronična opstruktivna bolest pluća (HOBP) se karakteriše inflamacijom kako u stabilnoj fazi bolesti tako i u toku egzacerbacije. Pokazano je da određeni medijatori zapaljenja imaju visoke nivoe u cirkulaciji, što ukazuje na sistemsku inflamaciju kod HOBP. HOBP ima brojne sistemske efekte $i$ komorbiditete, gde sistemska inflamacija ima značajnu ulogu. Prvi prepoznati sistemski efekat HOBP je poremećaj nutritivnog stanja. Određene bolesti, uključujući i HOBP, mogu dovesti do kaheksije gde dolazi do gubitka pre svega mišićne mase uprkos adekvatnom unosu kalorija. Takođe, sistemska inflamacija u HOBP ima uticaj na povećanje katabolizma proteina, što dovodi do smanjenja telesne mase. Povećana aktivnost enzima mijeloproteinaze (MMP) kod pacijenata sa HOBP može dovesti do istovremenog razvoja emfizema pluća i razvoja osteoporoze. Smatra se da je najvažnija uloga u vezi između HOBP $i$ kardiovaskularnih bolesti (CVD) takođe sistemska inflamacija. Nizak nivo inflamacije u malim disajnim putevima u HOBP $i$ aterosklerotičnom plaku može biti potencijalni faktor u razvoju oba patološka procesa. Sistemske manifestacije HOBP uključuju brojne endokrine poremećaje hipofize, štitaste žlezde, gonada, nadbubrežnih žlezda i pankreasa. Mehanizmi pomoću kojih HOBP utiče na endokrinu funkciju nisu sasvim jasni, ali verovatno uključuju hipoksemiju, hiperkapniju, sistemsku inflamaciju i upotrebu sistemskih glikokortikoida. Objašnjenje za značajne depresivne poremećaje u odmaklim stadijumima HOBP-a može biti izražena dispneja, smanjena fizička aktivnost, lošija tolerancija napora, česte egzacerbacije i sistemska inflamacija koje mogu dovesti do daljeg smanjenja fizičke aktivnosti, socijalne izolacije, straha i depresije.

Ključne reči: $H O B P$, sistemska inflamacija, sistemski efekat, komorbiditet.

a high level in systemic circulation, indicating systemic inflammation in COPD. The existence of systemic inflammation can be assessed by determining the levels of cytokines and acute phase reactants in the circulation, as well as the disorder of the number or function of inflammatory cells. 


\section{COPD AND NUTRITION DISORDER}

The first recognized systemic effect of COPD is a disorder of the state of nourishment. The terms "malnutrition" and "cachexia" are often used as synonyms and defined by BMI. Certain diseases, including COPD, can lead to cachexia where muscle and fat mass is lost despite adequate caloric intake. It has been shown that for patients with COPD with muscular atrophy and cachexia, there is a poor prognosis of the outcome of the disease, or a higher mortality compared to other patients with COPD. The causes of reduced energy intake in patients with HOBP are numerous: psychosocial reasons, functional damage to the gastrointestinal tract, dyspnoea, systemic inflammation, smoking, tissue hypoxia. Energy misbalance is also observed in patients with stable COPD and is worsening in a larger extent in patients in acute exacerbation of the disease. The association of systemic inflammation and malnutrition is shown. (1)

\section{COPD AND OBESITY}

It is believed that patients with COPD are at increased risk of developing obesity due to reduced daily physical activity. Also, repeated administration of systemic glucocorticoid increases the risk of obesity due to the redistribution of energy reserves and the increase in appetite. The prevalence of obesity is the greatest in the first and second stages according to COPD classification of GOLD. In addition to systemic inflammation in patients with COPD, a low degree of chronic inflammation is a mark of obesity. An inflammatory response that often occurs in obese patients could be triggered and maintained from increased fat tissue. Adipocytes secrete various adipokines, including cytokines, growth factors, adiponectin, resistin, adipsin, leptin, plasminogen activator inhibitor, lipoprotein lipase, and renin-angiotensin system components that may have a local and systemic effect. It can be assumed that in obese and in patients with relatively high mass of fatty tissue in the initial stages of COPD, fatty tissue can be an additional source of systemic inflammation. Since systemic inflammation is associated with a loss of skeletal muscle mass in COPD, it can intensify changes in body composition, leading to further loss of body weight and conservation of fat. Excretion of adipocin from fatty tissue in COPD can be enhanced by the presence of chronic or intermittent hypoxemia in advanced stages of the disease. (2)

\section{COPD AND SKELETAL MUSCLE DYSFUNCTION}

Skeletal muscles make up $40-50 \%$ of the total body weight in men with normal body weight. In chronic conditions such as COPD, the loss of muscle mass takes place faster. Today, the most important factors in the development of cachexia and muscular atrophy in COPD are considered to be: the imbalance between energy intake and consumption, physical inactivity, tissue hypoxia due to arterial hypoxemia, systemic inflammation and deficit of anabolic hormones. (3)

\section{COPD AND OSTEOPOROSIS}

Chronic systemic inflammation leads to the release of numerous chemoattractants and inflammatory markers as well as catabolic markers in circulation, including members of the matrix metalloproteinases family (MMPs) family. Cytokines TNF- $\alpha$, IL-1 $\beta$, and IL- 6 act as osteoclast stimulants that cause bone resorption. Inflammation in COPD also has an effect on increased protein catabolism, which leads to a decrease in body weight. Increased activity of MMP enzyme (primarily MMP-9 and MMP12) in patients with COPD can lead to lung tissue destruction and the development of osteoporosis. A significant correlation was found between the CTdetermined bone density of the thoracic spine CT of a specific lung emphysema, indicating the association of osteoporosis and emphysema. (4)

\section{COPD AND CARDIOVASCULAR DISORDERS}

In patients with COPD, cardiovascular system disorders (CVD) can be due to the development of pulmonary hypertension and dysfunction of the chambers due to increased intrathoracic pressure as a result of hyperinflation of the lungs. Smoking represents a common risk factor for coronary artery disease, cardiac insufficiency and COPD and can contribute to the dysfunction of both organic systems.

\section{COPD AND ISCHEMIC HEART DISEASE}

COPD and ischemic heart disease (IHD) are very common and are characterized by some common risk factors: smoking, older age and sedentary lifestyles. Faded FEV1 is an independent risk factor for fatal outcome due to myocardial infarction, as well as for IHD and when the smoking history of the subjects is controlled. Patients with mild and moderate COPD are at greater risk of developing lethal outcomes due to cardiovascular disease, primarily IHD, but due to respiratory insufficiency. One of the effects of smoking on the COPD that differs from the impact on IHD is to reduced risk of death from IHD after two years of stopping smoking, which is not the case for COPD. A large population study showed that patients with severe and very severe COPD were twice as likely to develop CVD disease and 1.6 times higher prevalence of hypertension as well as that the risk of taking hospital treatment due to CVD has increased. It is considered that 
the most important role in the association between COPD and CVD disease is systemic inflammation of low levels in COPD and atherosclerosis, which may be potential factors in the development of both pathological processes. Atherosclerotic plaques exhibit low-grade inflammation with an increased number of macrophages and secretion of INF-c by Th1 lymphocytes, similar to the peripheral lungs of patients with COPD. (4)

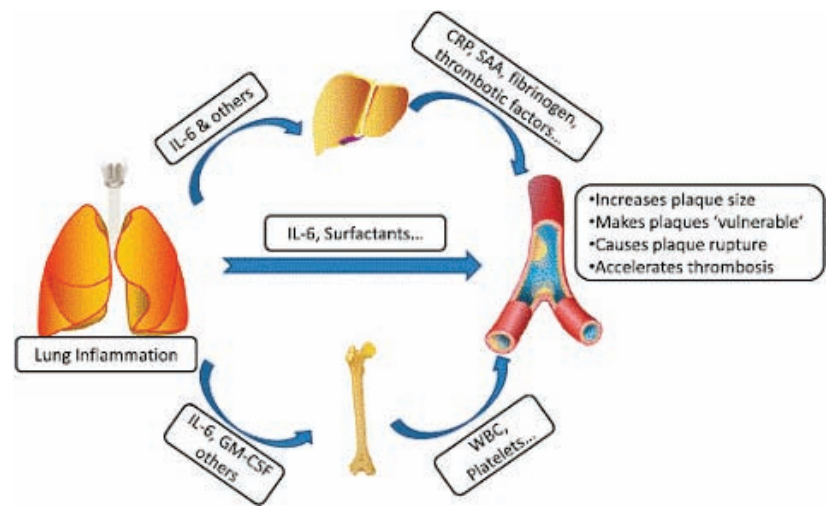

Figure 1. Proposed mechanism by which lung inflammation causes cardiovascular disease in chronic obstructive pulmonary disease (COPD). COPD is associated with chronic lung inflammation. Some inflammatory mediators such as IL-6, GM-CSF, and others escape into the systemic circulation and induce bone marrow to release inflammatory cells such as band cells, neutrophils, monocytes, and megakaryocytes that can directly invade atherosclerotic plaques. IL-6 and other inflammatory cells released by the lungs can also stimulate hepatocytes to release acute phase reactants such as CRP, SAA, fibrinogen, and procoagulant factors such as factor VIII into the systemic circulation, which together confer a "proinflammatory" phenotype to the plaques. The inflamed lungs can release inflammatory proteins such as IL-6 and certain surfactants that can directly promote atherogenesis. Thus, directly or indirectly (through the liver or bone marrow), the inflamed COPD lungs can make plaques more vulnerable by promoting their growth, increasing their lipid content, causing hemorrhage, and accelerating thrombosis (after plaque rupture or erosion). CRP 1/4 Creactive protein; GM-CSF 1/4 granulocyte macrophage colony-stimulating factor; SAA 1/4 serum amyloid A; $W B C 1 / 4$ white blood count.

\section{COPD AND CARDIAC INSUFFICIENCY}

Diagnosis of cardiac insufficiency in COPD is aggravated by the existence of common symptoms and clinical signs of the disease. Determination of type B natriuretic peptide or $\mathrm{N}$-terminal prohormone brain natriuretic peptide (NT-proBNP) is a good way to diagnose cardiac insufficiency in COPD and may be useful in distinguishing acute exacerbation of COPD from cardiac insufficiency. (5)

There is evidence that heart size has been reduced to COPD, especially in patients with pre-emptive lung emfysemia, and the intrathoracic blood volume has been reduced in patients with $\mathrm{HOBP}$ with hyperinflation of the lungs. Increasing the intrathoracic volume of the blood following the resection of the lung (volume reduction) and repairing the LV function indicates a greater significance of the change in intrathoracic pressure than parallel pathological changes in pulmonary and cardiac function due to systemic inflammation.

\section{COPD AND ENDOCRINE SYSTEM DISORDER}

Systemic manifestations of COPD include numerous endocrine disorders of the pituitary gland, thyroid gland, gonads, adrenal glands and pancreas. The mechanisms by which HOBP affects the endocrine function are not entirely clear, but are likely to include hypoxemia, hypercapnia, systemic inflammation, and the use of systemic glucocorticoids. An altered endocrine function may exacerbate the clinical manifestations of COPD by reducing anabolism and increasing protein catabolism, non-enzymatic glycosylation, and the activation of the renin-angiotensin-aldosterone system (RAAS). Systemic effects of endocrine disorders in patients with COPD can lead to disorders of breath control, weight loss and respiratory and peripheral skeletal muscle function, exacerbation of respiratory mechanics, effects on CVD, disorders of electrolyte and fluid balance. (7)

\section{COPD AND DISORDER OF THE GONADAL AXIS}

It has been observed that many men with COPD meet the criteria for the diagnosis of late hypogonadism. A noticeable decrease in testosterone levels contributes to the appearance of various symptoms and signs such as: energy level decrease, libido decline, bone density decrease, muscle mass decrease, and possibly decreased cognitive functions and memory. A set of these symptoms and signs is designated as late-onset hypogonadism. It has been shown that, in addition to aging, hypoxemia, hypercapnia, smoking, systemic glucocorticoids therapy and obesity, systemic inflammation may contribute to a decreased concentration of testosterone in circulation in males with COPD. TNF- $\alpha$, IL- $1 \beta$, IL- 6 , and other cytokines may reduce testosterone levels by enhancing aromatase activation, an enzyme that irreversibly converts testosterone to estradiol and disturbance of testosterone synthesis. (3)

\section{COPD AND GLYCO-REGULATION DISORDER}

The change in the function of fatty tissue in obese people plays an important role in the pathogenesis of insulin resistance. One of the characteristics of fat tissue in 
obesity is the increase in adipocytes as a result of a disorder of their differentiation. Hypertrophic adipocytes are overloaded with deposited triacylglycerol and their capacity for further lipid storage is reduced, especially postprandial. In COPD, the activity of enzymes involved in oxidative energy metabolism is reduced.

In case of large release of non-esterified fatty acids in circulation in patients with COPD, reduced oxidative capacity could pose a potential risk for the development of insulin resistance and metabolic syndrome. (8)

\section{COPD AND DEPRESSION}

The incidence of depressive disorder in COPD patients was $30.3 \%$ according to HADS. Data from clinical research show that in clinically stable patients with COPD, prevalence of depression which requires medical treatment varies in the $10-57 \%$ range.

In study Cekerevac, et al, was founded that the highest frequency and scores for depression evaluation were in the group of COPD patients with severe airflow limitation (9). Explanation for significant depressive disorder in more advanced stages in COPD can be expressive dyspnoea, decreased physical activity, worse exercise tolerance, frequent exacerbations and systemic inflammation which can lead to further physical activity decrease, social isolation, fear, and depression (10).

\section{CONCLUSION}

COPD is a systemic disease with a large number of diverse co-morbidities which could be attributed to it. Therefore, in patients with the presence of these comorbidities, and signs and symptoms of COPD, one should always consider this diagnosis and look for possible confirmation.

\section{REFERENCES}

1 Gea J, Sancho-Muñoz A, Chalela R. Nutritional status and muscle dysfunction in chronic respiratory diseases: stable phase versus acute exacerbations. J Thorac Dis. 2018; 10:1332-54.
2 Čekerevac I, Lazić Z. Gojaznost i hronična opstruktivna bolest pluća. Srp Arh Celok Lek 2011; 139: 322-32.

3 Novković Lj, Lazić Z, Petrović M, Ćupurdija V, Vujanac $\mathrm{K}$, Čekerevac I. Hypogonadism in chronic obstructive pulmonary disease (COPD) - Risk factors. Vojnosanit Pregl, 2017: DOI:10,22998/VSP170312081N.

4 Cuthbert JJ, Kearsley JW, Kazmi S, KallvikbakkaBennett A, Weston J, Davis J et al. The impact of heart failure and chronic obstructive pulmonary disease on mortality in patients presenting with breathlessness. Clin Res Cardiol. 2018; 8. doi: 10.1007/s00392-0181342-z.

5. Díez, J, López A, Hernández-Barrera V, , de MiguelYanes J, Méndez Bailón M, Muñoz-Rivas N et al. Influence of COPD on outcomes of patients hospitalized with heart failure: Analysis of the Spanish National Hospital Discharge Database (2001-2015). Int. J. Cardiol. 2018. S0167-5273(18)33503-4.DOI: https://doi.org/10.1016/j.ijcard.2018.07.067

6. Cuthbert JJ, Kearsley JW, Kazmi S, KallvikbakkaBennett A, Weston J, Davis J et al. Coronary lesions in patients with COPD (Global Initiative for Obstructive Lung Disease stages I-III) and suspected or confirmed coronary arterial disease. Int J Chron Obstruct Pulmon Dis. 2018:13; 1999-2006.

7. Čekerevac I. Sistemska inflamacija u hroničnoj opstruktivnoj bolesti pluća. Zadužbina Andrejević, Beograd, 2013.

8. Vujic T, Nagorni O, Maric G, Popovic L, Jankovic J. Metabolic syndrome in patients with chronic obstructive pulmonary disease: frequency and relationship with systemic inflammation. Hippokratia. 2016; 20:110-4.

9. Čekerevac I, Lazić Z, Novković Lj, Petrović M, Ćupurdija V, Todorović $\check{Z}$ et al. Characteristics of chronic obstructive pulmonary disease patients with depressive disorder. Srp Arh Celok Lek. 2017; 145:280-4.

10. Iyer A, Bhatt S, Garner J, J. Wells M, Trevor J, Patel N. Depression is associated with readmission for acute exacerbation of chronic obstructive pulmonary disease. Ann Am Thorac Soc. 2016. 13:197-203. 